\title{
Peranan Hukum Terhadap Konsumen Jual Beli Online di Indonesia
}

\author{
Wawan Fransisco \\ Fakultas Ekonomi \& Bisnis, Universitas Bina Insan, Lubuklinggau. \\ Email : wawanfransisco@gmail.com
}

\section{Info Artikel:}

| Diterima : 2 Agustus 2019

| Disetujui : 24 Desember 2019

| Dipublikasikan : 31 Desember 2019

\begin{abstract}
Abstrack
This scientific work is entitled the role of law on consumers of online buying and selling in Indonesia, in writing using normative legal research methods, namely by reading, studying, analyzing various laws and regulations, literature, scientific writings, and papers related to the material being examined.Online buying and selling is a way to shop through cyberspace or the internet where the payer uses a credit card or debit card, so without the need to meet face to face. Buyers or in this case consumers can order goods to sellers throughout Indonesia so easily. Therefore in this paper will explain in general about legal protection for consumers buying and selling online in Indonesian.
\end{abstract}

Keywords: Role of Law, Buying and Selling Online, Consumers.

\begin{abstract}
Abstrak
Penelitian ini mengkaji peran hukum dalam melindungi konsumen jual beli online di Indonesia, secara tertulis menggunakan metode penelitian hukum normatif, yaitu dengan membaca, mempelajari, menganalisis berbagai peraturan perundang-undangan, literatur, tulisan ilmiah, dan makalah yang berkaitan dengan kajian penelitian. Pembelian dan penjualan online merupakan cara untuk berbelanja melalui dunia maya atau internet di mana pembayar menggunakankartukreditataukartu debit tanpa harus bertemu secara langsung antara penjual dan konsumen. Pembeli atau dalam hal ini konsumen dapat memesan barang ke penjual di seluruh Indonesia dengan mudah. Karenanya dalam tulisan ini akan dijelaskan secara umum tentang perlindungan hukum bagi konsumen yang membeli dan menjual secara online dalam bahasa Indonesia.
\end{abstract}

Kata kunci: Peran Hukum, Jual Beli Online, Konsumen. 


\section{A. PENDAHULUAN}

Indonesia dikenal sebagai bangsa yang memiliki kegiatan jual beli online saat ini semakin marak, apalagi situs yang digunakan untuk melakukan transaksi jual beli online ini semakin baik dan beragam. Namun, seperti yang kita ketahui bahwa dalam sistem jual beli online produk yang ditawarkan hanya berupa penjelasan spesifikasi barang dan gambar yang tidak bisa dijamin kebenarannya. Untuk itu sebagai pembeli, maka sangat penting untuk mencari tahu kebenaran apakah barang yang ingin dibeli itu sudah sesuai atau tidak. Menurut Kamus Besar Bahasa Indonesia, jual beli adalah persetujuan saling mengikat antara penjual, yakni pihak yang menyerahkan barang, dan pembeli sebagai pihak yang membayar harga barang yang dijual. ${ }^{1}$ Menurut Rahmat Syafe ${ }^{e c}$, secara bahasa jual beli adalah pertukaran sesuatu dengan sesuatu yang lain. ${ }^{2}$ Sebelum adanya era globalisasi, kegiatan transaksi jual beli di lakukan dengan cara bertemu secara langsung antara penjual dan pembeli atau face to face. ${ }^{3}$ Transaksi perdagangan yang di dukung oleh perkembangan teknologi ini sering juga disebut E-Comerce. Akan tetapi banyak masyarakat yang menyebutnya sebagai transaksi perdagangan online atau saat ini dikenal dengan nama onlineshopping. Sejak

1 Departemen Pendidikan Nasional, Kamus Besar Bahasa Indonesia Pusat Bahasa, Edisi IV Cet.1, (Jakarta: PT Gramedia Pustaka, 2008), hlm. 589

2 Rahmat Syafe e'i, Fiqh Muamalah. Cet. X (Bandung: CV. Pustaka Setia, 2001), hlm. 73

${ }^{3}$ Abdul halim Barkattulah dan Teguh Prasetyo, 2005, Bisnis E-Comerce : Studi Sistem Keamanan dan Hukum di Indonesia, Cet. VII, Pustaka Pelajar, Yogyakarta, hlm.7 adanya internet ini, masyarakat yang ingin menjual barang-barang, atau jasa dapat menggunakan website situs jejaring sosial, maupun blog. Akan tetapi ternyata praktik jual beli secara online ini belum terlalu benar pelaksanaanya. Berdasarkan pengalaman dari beberapa orang yang pernah melakukan transaksi melalui orderan online merasa menjadi korban penipuan. Dimana barang-barang yang diperjual belikan tidak sesuai dengan pesanan pembeli atau barang yang di pesan tidak sampai ke tangan pembeli padahal proses pembayaran telah selesai dilakukan atau contoh yang dipasang pada website, situs jejaring sosial seperti Instagram, facebook, twitter, dan blog maupun yang ada pada forum jual beli lainya. Sehingga dalam hal ini pembeli merasa dirugikan, karena pembeli tidak memiliki perjanjian tertulis yang membolehkanya mengembalikan barang yang tidak sesuai pesanan tersebut dan biasanya ada juga para penjual yang tidak membolehkan para pembeli untuk mengembalikanya. Pembeli sendiri bingung untuk melakukan tindakan, dikarenakan tidak memiliki bukti tertulis yang dapat menunjukan bahwa pelaku usaha atau penjual telah melakukan kelalaian. Oleh karena itu kedudukan konsumen di Indonesia memerlukan perhatian yang cukup besar.

Dalam transaksi jual beli online, penjual dan pembeli tidak bertemu langsung dalam satu tempat melainkan melalui dunia maya. Adapun yang menjadi subjek jual beli online tidak berbeda dengan jual beli secara konvensional, yaitu pelaku usaha selaku penjual yang menjual barangnya dan pembeli sebagai konsumen yang 
membayar harga barang. Penjualan dan pembelian online terkadang hanya dilandasi oleh kepercayaan, artinya pelaku jual beli online kadang tidak jelas sehingga rentan terjadinya penipuan. Adapun yang menjadi objek jual beli online, yaitu barang atau jasa yang dibeli oleh konsumen, namun barang atau jasa tidak dilihat langsung oleh pembeli selaku subjek jual beli online. Sangat berbeda dengan jual beli secara konvensional dimana penjual dan pembeli dapat bertemu dan melihat objek jual beli secara langsung, sehingga memungkinkan pembeli mendapatkan kepastian terkait dengan kualitas barang yang ingin dibelinya, sehingga sangat minim terjadi tindakan penipuan. ${ }^{4}$

Konsumen jual beli online semakin dituntut untuk mengetahui lebih dalam mengenai proses, resiko serta keamanan dari sebuah transaksi online. Saat ini jenis transaksi online juga semakin beragam mulai dari jenis konvensional dimana pembeli dan penjual harus bertatap muka dalam melakukan proses transaksi hingga yang menggunakan proses transaksi otomatis tanpa harus bertatap muka. Di Indonesia sendiri ada beberapa jenis transaksi jual beli online yang biasa dilakukan oleh konsumen jual beli online, yaitu: 5

a. Transfer Antar Bank

Transaksi dengan cara transfer antar bank merupakan jenis transaksi yang paling umum dan popular digunakan oleh para

4 Teguh Prasetyo, Bisnis E-Commerce Studi Sistem Keamanan dan Hukum d Indonesia, (Yogyakarta: Pustaka Pelajar, 2005), hlm. 66

${ }^{5}$ Nurul Atira, Jual Beli Online yang Aman dan Syar'i, (Makasar: UIN Alaluddun Makasar, 2017), hlm. 32 pelaku usaha atau penjual online. Jenis transaksi ini juga memudahkan proses konfirmasi karena dana bisa dengan cepat di chek oleh penerima dana atau penjual. Prosesnya adalah pertama-tama konsumen mengirim dana yang telah disepakati lalu setelah dana masuk, maka penjual akan mengirimkan barang transaksi yang dijanjikan.

b. COD (Cash On Delivery)

Pada sistem COD sebenarnya hampir dapat dikatakan bukan sebagai proses jual beli secara online, karena penjual dan pembeli terlibat secara langsung, bertemu, tawarmenawar, dan memeriksa kondisi barang baru kemudian membayar harga barang. Keuntungan dari sistem ini adalah antara pelaku usaha dan konsumen lebih bisa leluasa dalam proses transaksi. Konsumen bisa melihat dengan detil barang yang akan dibeli. Jenis transaksi ini dipopulerkan oleh website jual beli seperti Tokobagus, Berniaga, dan lainnya. Kekurangan dari sistem ini adalah keamanan baik pelaku usaha maupun konsumen karena boleh jadi pihak yang akan ditemui pelaku usaha atau konsumen adalah orang yang berniat jahat.

c. Kartu Kredit Kartu

kredit merupakan alat pembayaran yang semakin popular, selain memberikan 
kemudahan dana proses verifikasi, pembeli juga tidak perlu melakukan semua tahap transaksi. Akan tetapi karena tidak semua pembeli mempunyai kartu kredit sehingga cara pembayaran ini menjadi pilihan kedua. Bahkan pengguna dengan kartu kredit pun akan berusaha memastikan bahwa toko si pelaku usaha memiliki tingkat keamanan yang tinggi guna menghindari tindakan pencurian data oleh pihak-pihak tertentu. ${ }^{6}$

d. Rekening Bersama

Jenis transaksi ini disebut juga dengan istilah escrow. Cara pembayaran ini mempunyai perbedaan dengan proses pembayaran melalui transfer bank. Jika dalam transfer bank pihak ketiganya adalah bank, sedangkan dengan sistem rekening bersama yang menjadi pihak ketiga adalah lembaga pembayaran yang telah dipercaya baik oleh pihak pelaku usaha maupun konsumen. Prosesnya, yaitu pertama konsumen mentransfer dana ke pihak lembaga rekening bersama. Setelah dana dikonfirmasi masuk, lalu pihak rekening bersama meminta pelaku usaha mengirim barang yang sudah disepakati. Jika barang sudah sampai, baru dana tersebut diberikan pada si pelaku usaha. e. Potongan Pulsa

Metode pemotongan pulsa biasanya diterapkan oleh toko online yang menjual produkproduk digital seperti aplikasi, musik, ringtone, dan permainan. Transaksi ini masih didominasi oleh transaksi menggunakan perangkat seluler atau smartphone. ${ }^{7}$

Dalam memandang hukum sebagai alat kontrol sosial manusia, maka hukum merupakan salah satu alat pengendali sosial. Alat lain masih ada sebab masih saja diakui keberadaan pranata sosial lainnya (misalnya keyakinan, kesusilaan). Kontrol sosial merupakan aspek normatif kehidupan sosial. Hal itu bahkan dapat dinyatakan sebagai pemberi defenisi tingkahg laku yang menyimpang dan akibat-akibat yang ditimbulkannya, seperti berbagai larangan, tuntutan, dan pemberian ganti rugi. ${ }^{8}$ Hukum sebagai alat kontrol sosial memberikan arti bahwa ia merupakan sesuatu yang dapat menetapkan tingkah laku manusia. Tingkah laku ini dapat didefenisikan sebagai sesuatu yang menyimpang terhadap aturan hukum. Sebagai akibatnya, hukum dapat memberikan sanksi atau tindakan terhadap si pelanggar. Karena itu, hukum pun menetapkan sanksi yang harus diterima oleh pelakunya. Hal ini berarti bahwa hukum mengarahkan agar masyarakat berbuat secara benar menurut aturan sehingga ketentraman terwujud. ${ }^{9}$ Sanksi hukum terhadap perilaku yang menyimpang, ternyata terdapat perbedaan

\footnotetext{
${ }^{7}$ Ibid., hlm. 34

8 Satjipto Rahardjo, Hukum Dan Perubahan Sosial (Bandung :Alumni, 1983), hlm. 35.

${ }^{9}$ Ibid. hlm. 35
} 
dikalangan suatu masyarakat. Tampaknya hal ini sangat berkait dengan banyak hal, seperti keyakinan agama, aliran falsafat yang dianut. Dengan kata lain, sanksi ini berkaitan dengan kontrol sosial. Ahmad Ali menyebutkan sanksi pezina berbeda bagi masyarakat penganut Islam secara konsekuen dengan masyarakat Eropa Barat. ${ }^{10}$ Orang Islam memberikan sanksi yang lebih berat, sedangkan orang Eropa Barat memberi sanksi yang ringan saja. Hukum, di samping bukan satusatunya alat kontrol sosial, juga sebagai alat pengendali memainkan peran pasif. Artinya bahwa hukum menyesuaikan diri dengan kenyataan masyarakat yang dipengaruhi oleh keyakinan dan ajaran falsafat lain yang diperpeganginya.

Dalam hal ini, fungsi hukum ini lebih diperluas sehingga tidak hanya dalam bentuk paksaan. Fungsi ini dapat dijalankan oleh dua bentuk: 1) pihak penguasa negara. Fungsi ini dijalankan oleh suatu kekuasaan terpusat yang berwujud kekuasaan negara yang dilaksanakan oleh the ruling class tertentu. Hukumnya biasanya dalam bentuk hukum tertulis dan perundang-undangan. 2) masyarakat; fungsi ini dijalankan sendiri oleh masyarakat dari bawah. Hukumnya biasa berbentuk tidak tertulis atau hukum kebiasaan.

Fungsi hukum sebagai alat kontrol sosial dapat berjalan dengan baik bila terdapat hal-hal yang mendukungnya. Pelaksanaan fungsi ini sangat berkaitan dengan materi hukum yang baik dan jelas. Selain itu, pihak pelaksana sangat menentukan. Orang yang akan

10 Ahmad Ali, Keterpurukan Hukum di Indonesia penyebab dan solusinya (Jakarta:Galiah, 2002), hlm. 27 melaksanakan hukum ini tidak kalah peranannya. Suatu aturan atau hukum yang sudah memenuhi harapan suatu masyarakat serta mendapat dukungan, belum tentu dapat berjalan dengan baik bila tidak didukung oleh aparat pelaksana yang kimit terhadap pelaksanaan hukum. Hal yang terakhir inilah yang sering dikeluhkan oleh masyarakat Indonesia. Aparat sepertinya dapat dipengaruhi oleh unsur-unsur lain yang sepatutnya tidak menjadi faktor penentu, seperti kekuasaan, materi dan pamrih serta kolusi. Citra penegak hukum masih rawan. ${ }^{11}$

Hukum sebagai rekayasa sosial Adanya fungsi hukum sebagai alat rekayasa sosial, Suatu masyarakat dimanapun di dunia ini, tidak ada yang statis. Masyarakat manapun senantiasa mengalami perubahan, hanya saja ada masyarakat yang perubahannya pesat dan ada pula yang lamban. Didalam menyesuaikan diri dengan perubahan itulah, fungsi hukum sebagai a tool of engineering, sebagai perekayasa sosial, sebagai alat untuk merubah masyarakat ke suatu tujuan yang diinginkan bersama. ${ }^{12}$ Sejalan dengan ini mengutip pendapat Satjipto Rahardjo ${ }^{13}$ menyatakan bahwa "Hukum sebagai sarana rekayasa sosial, innovasi, sosial engineering, menurut Satjipto Rahardjo, tidak saja digunakan untuk mengukuhkan pola-pola kebiasaan dan tingkah laku yang terdapat dalam masyarakat, melainkan juga untuk mengarahkan pada tujuan-tujuan yang

\footnotetext{
11 Ali Aspandi, Menggugat Sistem Hukum Peradilan Indonesia yang penuh ketidak pastian, (Surabaya: LeKSHI, tt).

12 Soerjono Soekanto, Pokok-Pokok Sosiologi Hukum (Jakarta:PT.Raja Grafindo persada, 2000), hlm. 79

13 Satjipto Rahardjo, Hukum Dan Perubahan Sosial (Bandung:Alumni, 1983),hlm.39
} 
dikehendaki, menghapuskan kebiasaankebiasaan yang dipandang tidak perlu lagi, menciptakan pola-pola kelakuan baru dan sebagainya".

Fungsi hukum sebagai sarana untuk mengatur sebaik mungkin dan memperlancar proses interaksi sosial sehingga terwujudlah masyarakat yang harmonis, aman dan sejahtera (baldatun toyyibatun warabbun ghafur merupakan bukti yang kuat betapa konteks sosial sangat berpengaruh dalam menentukan produk hukum yang timbul. Dikalangan fuqaha misalnya, adanya dinamika pemikiran antara Syafi'i dengan qaul qadim dan qaul jadid-nya, Malik dengan maslahah mursalah-nya, Abu Hanifah dengan pemikiran rasionalnya, dan Ibn Hambal dengan pemikiran tradisionalnya (salaf) menunjukkan betapa interaksi dialogis mereka dengan konteks sosial masyarakat dan dimana mereka hidup dapat mempengaruhi bentuk dan pemahaman mereka tentang syariat. ${ }^{14}$

Dalam kehidupan bermasyarakat, hukum telah memainkan peranan yang sangat penting dalam menjaga ketertiban dan ketentraman. Hal ini disebabkan karena hukum mengatur agar kepentingan masing-masing individu tidak bersinggungan dengan kepentingan umum, mengatur mengenai pelaksanaan hak dan kewajiban masyarakat atau para pihak dalam suatu hubungan hukum dan lain sebagainya. ${ }^{15}$ Apa yang diharapkan dari

14 Muhammad Ali Sais, Tarikh al-Fiqh al-Islami (Mesir: Mathba'ah al-Nahda,1957), hlm. 104; lihat juga Husain Hamid Hasan, tt, al-Madkhal li Dirasat al-Fiqh al-Islami (Mesir: Mathba ah alNahdah), hlm. 33.

15 Muhammad Daud Ali, Hukum Islam Pengantar Ilmu Hukum dan Tata Hukum Islam di Indonesia (Jakarta: Raja Grafindo persada, 2011), hlm.43 hukum adalah bekerjanya fungsi hukum. Dengan bekerjanya fungsi hukum sebagaimana mestinya maka penegakan hukum menjadi sangat mungkin diwujudkan. Mengapa hukum selama ini lemah, karena fungsi hukum tidak berjalan dengan baik bila tidak ingin dikatakan stagnan. Stagnansi disebabkan oleh banyak faktor yang kemudian sering menjadi perdebatan atau bahan diskusi para ahli dan pakar hukum di media massa. ${ }^{16}$

\section{B. METODE PENELITIAN}

Tulisan ini menggunakan metode penulisan hukum normatif karena meneliti peraturan perundang-undangan, literatur, dan makalah yang berkaitan dengan materi yang di teliti, yang terdiri dari jenis data yang diperoleh dalam penelitian ini adalah data skunder yaitu data yang diperoleh dari penelitian kepustakaan dan dokumnetasi,yang merupakan hasil penelitian dan pengolahan orang lain, yang sudah tersedia dalam bentuk literatur atau dokumentasi.

\section{HASIL DAN PEMBAHASAN}

\section{Peranan Hukum dalam Melindungi Jual Beli Online}

Hukum berfungsi sebagai sarana untuk menertibkan masyarakat dan mengatur pergaulan hidup masyarakat, serta sarana untuk menyelesaikan sengketa atau pertikaian dalam masyarakat. ${ }^{17}$ Sedangkan menurut Prof. Dr.

\footnotetext{
16 Noel J.Coulson, Hukum Islam dalam Perspektif Sejarah (Jakarta: P3M, 1987). hlm. 55.

17 Soerjono soekanto, Faktor-faktor yang mempengaruhi Penegakan Hukum(Jakarta:PT Raja Grafindo Persada, 2002), hlm. 77
} 
Soerjono Soekanto, "Sebagai alat untuk melaksanakan ketertiban dan ketentraman dalam kehidupan bermasyarakat dan sarana untuk mewujudkan keadilan sosial, baik lahir maupun bathin serta menggerakkan pembangunan bagi masyarakat."

Dalam hal rumusan mengenai fungsi hukum terdapat rumusan yang relatif sama diantara para pakar. Namun secara umum substansi rumusan tersebut hampir sama. Secara pragmatis hukum di Indonesia sekarang ini telah dikuasai oleh mafia peradilan. Hukum dan lembaga peradilan yang ada tidak lagi menjadi benteng terakhir bagi para pencari keadilan. Hal tersebut menyebabkan masyarakat seringkali main hakim sendiri dalam menyelesaikan kasuskasus yang dihadapinya. Sebagai konsekuensinya, bukannya kejahatan dapat ditekan malah semakin merebak. Oleh karena itu, sebagai langkah awal untuk menekan merebaknya kekerasan akibat buruknya tingkat kepercayaan masyarakat terhadap pemerintah dan penegak hukum, menurutnya perlu adanya upaya untuk mengembalikan kepercayaan warga masyarakat terhadap hukum dan penegak hukum. ${ }^{18}$

Istilah konsumen juga dapat kita temukan dalam peraturan perundangundangan Indonesia. Secara yuridis formal pengertian konsumen

18 Ahmad Ali, "Penegakan Syariat Islam (Suatu Tinjauan Sosiologi Hukum)," Makalah disampaikan pada seminar Nasional Penegakan Syariat Islam melalui Otonomi Khusus ditinjau dari Berbagai Aspek (Makassar, 22 Juni 2001), hlm. 7. dimuat dalam Pasal 1 angka 2 UU No. 8 Tahun 1999 tentang Perlindungan Konsumen, "konsumen adalah setiap orang pemakai barang dan/ atau jasa yang tersedia dalam masyarakat, baik bagi kepentingan diri sendiri, keluarga, orang lain, maupun makhluk hidup lain dan tidak untuk diperdagangkan". ${ }^{19}$

Berbagai informasi bisa di dapatkan di internet, mulai dari informasi ekonomi, bisnis, pendidikan, hiburan dan lain-lain. Para pihak yang melakukan transaksi lewat internet dapat merasa yakin akan keaslian dan kesempurnaan suatu pesan yang ada diterima atau dikirimnya lewat internet, dan bagaimana caranya suatu pihak saling menyetujui dokumen yang di kirim lewat internet, seperti kontrak jual beli lewat internet. Pada awal diperkenalkannya internet, ada perjanjian tidak tertulis yang lahir antara penyedia jasa di internet bahwa mereka akan meneruskan setiap lalu lintas data dan informasi yang diterima. Jika ditinjau dari lahirnya internet dalam kehidupan manusia, pengaruh internet dalam dunia bisnis atau perdagangan sangat besar.

Sistem perdagangan dengan
memanfaatkan sarana internet
(interconnection networking), yang
selanjutnya disebut e-commerce telah
mengubah wajah dunia bisnis di
dunia. Selain tuntutan perkembangan
teknologi informasi, e-commerce lahir
atas tuntutan masyarakat terhadap
pelayanan yang serba cepat, mudah,

19 UU No. 8 Tahun 1999 tentang Perlindungan Konsumen 
praktis dan memiliki ruang gerak yang lebih luas dalam memiliki ruang gerak yang lebih luas dalam memiliki produk (barang dan jasa) yang akan dipergunakan dengan kualitas dan kuantitas yang diinginkan pengguna internet untuk keperluan bisnis dan perdagangan mulai dikenal beberapa tahun belakangan ini dan dengan cepat meluas, terutama di negara-negara maju. ${ }^{20}$ Di Indonesia, fenomena $e$ commerce sudah dikenal sejak tahun 1996 dengan munculnya situs http://www.sanur.com sebagai toko buku on-line Universitas Sumatera Utara pertama.

Transaksi online ini terdapat pada media elektronik yang secara fisik tidak memerlukan pertemuan para pihak yang bertransaksi dan keberadaan media ini dalam public network atas sistem yang berlawanan dengan private network. Pasal 1 Angka 3 Undang-Undang Nomor 11 Tahun 2008 tentang Informasi dan Transaksi Elektronik dijelaskan mengenai definisi perdagangan secara elektronik yaitu perdagangan barang maupun jasa yang dilakukan melalui jaringan komputer atau media elektronik lainnya. Sementara itu, Pasal 1 Angka 5 Undang-Undang Nomor 11 Tahun 2008 tentang Informasi dan Transaksi Elektronik menjelaskan pula mengenai definisi dari Kontrak Elektronik yaitu dokumen elektronik yang membuat transaksi dan atau perdagangan elektronik. Undang-Undang Nomor 11

20 Dikdik M.Arief Mansur,Elisatris Gultom, Cyber Law.(Bandung:Refika Aditama,2005) hlm.144
Tahun 2008 tentang Informasi dan Transaksi Elektronik di atas, prinsipprinsip model law on electronic, menjelaskan bahwa: ${ }^{21}$

1. Segala bentuk informasi elektronik dalam bentuk data elektronik memiliki akibat hukum, keabsahan ataupun kekuatan hukum.

2. Dalam hal adanya suatu informasi harus dalam bentuk tertulis, maka suatu data elektronik dapat memenuhi syarat.

3. Dalam hal tanda tangan, maka tanda tangan elektronik itu merupakan tanda tangan yang sah.

4. Dalam hal kekuatan pembuktian data yang bersangkutan, maka data elektronik berupa pesan memiliki kekuatan dalam pembuktian.

Adapun dalam pasal 27 Undang-Undang Nomor 11 Tahun 2008 tentang Informasi dan Transaksi Elektronik menjelaskan tentang perbuatan yang dilarang antara lain: ${ }^{22}$

1. Setiap orang dengan sengaja dan tanpa hak mendistribusikan dan/atau mentransmisikan dan/atau membuat dapat diaksesnya Informasi Elektronik dan/atau

21 Harso Wijaya, Tinjauan Hukum Mengenai Wanprestasi Dalam Jual Beli Secara Elektronik Dihubungkan Dengan Buku III Kitab UndangUndang Hukum Perdata Tentang Perikatan (Jakarta: Fakultas Hukum Universitas Kristen Indonesia, 2005), hlm. 35

${ }^{22}$ Undang-undang RI Nomor 11 Tahun 2008 tentang Informasi dan Transaksi Elektronik, Pasal 2745 
Dokumen Elektronik yang memiliki muatan yang melanggar kesusilaan.

2. Setiap orang dengan sengaja dan tanpa hak mendistribusikan dan/atau mentransmisikan dan/atau membuat dapat diaksesnya Informasi Elektronik dan/atau Dokumen Elektronik yang memiliki muatan perjudian.

3. Setiap orang dengan sengaja dan tanpa hak mendistribusikan dan/atau mentransmisikan dan/atau membuat dapat diaksesnya Informasi Elektronik dan/atau Dokumen Elektronik yang memiliki muatan penghinaan dan/atau pencemaran nama baik.

4. Setiap orang dengan sengaja dan tanpa hak mendistribusikan dan/atau mentransmisikan dan/atau membuat dapat diaksesnya Informasi Elektronik dan/atau Dokumen Elektronik yang memiliki muatan pemerasan dan/atau pengancaman

\section{Bentuk Perlindungan Hukum Terhadap Konsumen Jual Beli Online}

Bentuk perlindungan terhadap masyarakat mempunyai banyak dimensi yang salah satunya yaitu perlindungan hukum. Adanya benturan kepentingan didalam masyarakat harus dapat diminimalisasi dengan kehadiran hukum dalam masyarakat. Adanya perlindungan hukum bagi seluruh rakyat Indonesia dapat ditemukan dalam Undangundang Dasar Negara Republik Indonesia 1945 (UUD 1945), oleh karena itu maka setiap produk yang dihasilkan oleh legislatif harus mampu memberikan perlindungan hukum bagi seluruh masyarakat. Terdapat beberapa pendapat para sarjana mengenai perlindungan hukum, antara lain:

a. Menurut Satjipto Rahardjo, perlindungan hukum adalah adanya upaya melindungi kepentingan seseorang dengan cara mengalokasikan suatu kekuasaan kepadanya untuk bertindak dalam rangka kepentingannya tersebut ${ }^{23}$

b. Menurut Philipus M. Hadjon, perlindungan hukum diartikan sebagai tindakan melindungi atau memberikan pertolongan kepada subyek hukum dengan perangkat-perangkat hukum. Bila melihat pengertian perlindungan hukum diatas, maka dapat diketahui unsur-unsur dari perlindungan hukum, yaitu: ${ }^{24}$ subyek yang melindungi, obyek yang akan dilindungi alat, instrumen maupun upaya yang digunakan untuk

\footnotetext{
23 Satjipto Rahardjo.Sisi-sisi Lain dari Hukum di Indonesia, Jakarta, Kompas, 2003. hlm.121.

${ }^{24}$ Philipus M. Hadjon,dkk. Pengantar Hukum Administrasi Indonesia,Gajah Mada University Press, Yogyakarta, 2011. hlm.10
} 
tercapainya perlindungan

tersebut.

Dari beberapa pengertian mengenai perlindungan hukum di atas, dapat disimpulkan bahwa perlindungan hukum sebagai suatu upaya untuk melindungi kepentingan individu atas kedudukannya sebagai manusia yang mempunyai hak untuk menikmati martabatnya, dengan memberikan kewenangan padanya untuk bertindak dalam rangka kepentingannya tersebut. Menurut Pasal 1 angka 1 UU No.8 Tahun 1999 tentang Perlindungan Konsumen menyatakan bahwa "Perlindungan konsumen adalah "segala upaya yang menjamin adanya kepastian hukum untuk memberi perlindungan kepada konsumen". Kalimat yang menyatakan "segala upaya yang menjamin adanya kepastian hukum". ${ }^{25}$

$$
\text { Salah satu hasil }
$$

perkembangan ilmu pengetahuan dan teknologi yaitu pada transaksi jual beli secara elektronik, sama halnya transaksi jual beli yang biasa di lakukan di dunia nyata, dilakukan oleh para pihak yang terkait, walaupun dalam jual beli secara online ini pihak-pihak tidak bertemu secara langsung satu sama lain, tetapi berhubungan dengan media internet. Pada dasarnya pihak- pihak daslam jual beli secara online tersebut

25 Inosentius Samsul. Perlindungan Konsumen, Kemungkinan Penerapan Tanggung Jawab Mutlak, Universitas Indonesia, Jakarta, 2004. hlm.131 masing-masing memiliki hak dan kewajiban yang harus dilaksanakan sesuai dengan Undang-Undang No 8 Thun 1999 tentang Perlindungan konsumen. Undang-Undang No 8 Tahun 1999 tentang Perlindungan Konsumen yang sering disebut dengan UUPK dalam Pasal 1 angka 1 memberikan definisi bahwa : perlindungan konsumen adalah segala upaya yang menjamin adanya kepastian hukum untuk memberi perlindungan hukum terhadap konsumen. Tujuan yang ingin dicapai perlindungan konsumen dalam pasal 3 umumnya dapat dibagi dalam 3 bagian yaitu :

1. Memberdayakan konsumen dalam memilih, menentukan barang, dan menuntut haknya,

2. Menciptakan sistem perlindungan konsumen yang memuat unsur- unsur kepastian hukum, keterbukaan informasi, dan akses untuk mendapatkan informasi tersebut,dan

3. Menumbuhkan kesadaran pelaku usaha mengenai pentingnya perlindungan konsumen sehingga tumbuh sikap jujur dan bertanggung jawab. $^{26}$

Di ungkapkanya UndangUndang No 8 Tahun 1999 tentang Perlindungan konsumen di dasari oleh rasio : Perlindungan konsumen dari bahaya-bahaya terhadap kesehatan, promosi dan perlindungan

26 AZ Nasution. Aspek Hukum Perlindungan Konsumen Tinjauan Singkat UU No 8 Tahun 1999 LN 1999 No 42, pemantau peradilan .com,h.1-2. 
kepentingan sosial konsumen. Menurut Johanes Gunawan, perlindungan hukum terhadap konsumen dapat dilakukan pada saat sebelum terjadinya transaksi (no conflict/pre purchase) dan/atau pada saat setelah terjadinya transaksi (conflict/post purchase). ${ }^{27}$ Hukum konsumen dalam hukum perdata dalam arti luas adalah termasuk hukum perdata, hukum dagang serta kaidah-kaidah keperdataan yang termuat dalam berbagai peraturan perundang-undangan lainnya. Baik hukum perdata tertulis dan tidak tertulis. Kaidah-kaidah hukum perdata umumnya termuat dalam KUHPerdata. ${ }^{28}$

Di Negara Indonesia sebenarnya ada beberapa hal yang mengarah kepada penggunaan dan pengakuan dokumen elektronik sebagai alat bukti yang sah, misalnya: (a) Dikenalnya online trading dalam kegiatan bursa efek; (b) Pengaturan mikro film sebagai media penyimpanan dokumen Perusahaan yang telah diberi kedudukan sebagai alat bukti tertulis otentik dalam Undang-Undang Nomor 8 Tahun 1997 tentang Dokumen Perusahaan. Namun demikian pengaturan semacam ini tidak dapat menunjang dan mengakomodir jalannya cyberspace pada umumnya dan transaksi $e$ commerce pada khususnya. ${ }^{29}$

${ }^{27}$ Johanes Gunawan, Hukum Perlindungan Konsumen, Universitas Katolik Parahyangan, Bandung, hal. 3

${ }^{28}$ Mariam Darus Badrulzaman.Aneka Hukum Bisnis, Bandung: Alumni, 1994. hlm. 14.

${ }^{29}$ Ahmad M. Ramli, dkk.Menuju Kepastian Hukum di Bidang Informasi dan Transaksi Elektronik, Jakarta:
Perlindungan konsumen
dalam transaksi online merupakan suatu hal yang sangat penting dalam hubungan antara pelaku usaha dengan konsumen. Untuk menjamin adanya kepastian hukum untuk memberi perlindungan kepada pembeli selaku konsumen. ${ }^{30}$ Undangundang perlindungan konsumen yang telah mengatur hak dan kewajiban bagi pihak konsumen dan pelaku usaha bahkan juga mengatur tentang larangan terhadap perbuatan yang tidak dapat dilakukan oleh pelaku usaha. Hal tersebut diatur dalam pasal 4 sampai pasal 17 UndangUndang No 18 Tahun 1999 tentang Perlidungan Konsumen. ${ }^{31}$ Pasal 4 UUPK menemukan bahwa hak konsumen yang berhubungan dengan penelitian adalah : Hak atas kenyamanan, keamanan, dan keselamatan dalam mengkonsumsi barang atau jasa. Hak ini dimaksudkan agar konsumen terhindar dari kerugian fisik maupun psikis apabila menggunakan suatu produk, Hak untuk memilih barang dan jasa seta mendapatkan barang dan atau jasa tersebut sesuai dengan nilai tukar dan kondisi serta jaminan yang dijanjikan. Tanggung jawab pelaku usaha sesuai ketentuan Pasal 19 yaitu :

1. Pelaku usaha bertanggung jawab memberikan ganti rugi atas kerusakan, pencemaran,

Departemen Komunikasi dan Informatika Republik Indonesia, 2007. hlm. 56.

30 Nasution AZ. Hukum Perlindungan Konsumen, Diadit Media, Yogyakarta, 2001. hlm 18.

${ }^{31}$ Nasution AZ. Konsumen dan Hukum, Pustaka Sinar Harapan, Jakarta, 1995. hlm. 32-35 
dan/atau kerugian konsumen akibat mengkonsumsi barang dan/atau jasa yang dihasilkan atau diperdagangkan. ${ }^{32}$

2. Ganti rugi sebagaimana dimaksud pada ayat (1) dapat berupa pengembalian uang atau penggantian barang dan/atau jasa yang sejenis atau setara nilainya, atau perawatan kesehatan dan/atau pemberian santunan yang sesuai dengan ketentuan peraturan perundangundangan yang berlaku.

3. Pemberian ganti rugi dilaksanakan dalam tenggang waktu 7 (tujuh) hari setelah tanggaltransaksi.

\section{KESIMPULAN}

Jual beli Online adalah cara berbelanja melalui dunia maya atau internet, dimana pembayaranya menggunakan kartu kredit atau kartu debit. Undang-Undang No. 8 Tahun 1999 Tentang perlindungan konsumen nyatanya telah dilaksanakan untuk mengakomodasi kepentingan konsumen baik itu hak maupun kewajiban yang melakukan transaksi online shopping. Hal ini terlihat dari dicantumkanya hak konsumen dalam Pasal 4, serta dalam pelaksanaanya sendiri hak konsumen sudah terlindungi, hal ini dapat terlihat dari dicantumkanya instruksi dan tips pemakaian produk, sehingga konsumen mengerti penggunaan barang, konsumen juga berhak untuk memilih barang yang dikehendaki serta memperoleh jaminan seperti yang dijanjikan, dan konsumen sudah memperoleh informasi yang jelas dan baik dari pelaku usaha atas produk atau barang yang akan dibeli dari penjual.

Hukum sebagai sosial kontrol, sosial engineering dan soasial welfare:

1. Berperan aktif sebagai sesuatu yang dapat menetapkan tingkah laku manusia. Tingkah laku yang menyimpang terhadap aturan hukum. Sehingga hukum dapat memberikan sanksi atau tindakan terhadap si pelanggar.

2. Berperan sebagai rekayasa sosial dalam proses perubahan masyarakat yang di manapun senantiasa terjadi, apalagi dalam kondisi kemajuan yang menuntut perlunya perubahan-perubahan yang relatif cepat. sebagai a tool of engineering yang pada prinsipnya merupakan arahan untuk merubah pola-pola tertentu dalam suatu masyarakat, baik dalam arti mengokohkan suatu kebiasaan menjadi sesuatu yang lebih diyakini dan lebih ditaati, maupun dalam bentuk perubahan lain.

3. Demikian halnya sebagai welfare berperan dan merupakan sarana untuk mengatur sebaik mungkin dan memperlancar proses interaksi sosial sehingga terwujudlah masyarakat yang harmonis, aman dan sejahtera (baldatun toyyibatun warabbun ghafur).

\footnotetext{
32 Sriwati. Perlindungan Hukum Bagi Para Pihak dalam Perjanjian Baku,Yustika,Jakarta,2000. hlm 22
} 


\section{DAFTAR PUSTAKA}

Abdul halim Barkattulah dan Teguh Prasetyo, 2005, Bisnis E-Comerce : Studi Sistem Keamanan dan Hukum di Indonesia, Cet. VII, Pustaka Pelajar:Yogyakarta.

Ahmad Ali,2001 "Penegakan Syariat Islam (Suatu Tinjauan Sosiologi Hukum)," Makalah disampaikan pada seminar Nasional Penegakan Syariat Islam melalui Otonomi Khusus ditinjau dari Berbagai Aspek, Makassar.

Ahmad Ali, 2002. Keterpurukan Hukum di Indonesia penyebab dan solusinya. Galiah : Jakarta.

Ahmad M. Ramli, dkk., 2007, Мепији Kepastian Hukum di Bidang Informasi dan Transaksi Elektronik, : Departemen Komunikasi dan Informatika Republik Indonesia : Jakarta.

Ali Aspandi, Menggugat Sistem Hukum Peradilan Indonesia yang penuh ketidak pastian, (Surabaya: LeKSHI, $\mathrm{tt}$ ).

AZ Nasution, Aspek Hukum Perlindungan Konsumen Tinjauan Singkat UU No.8 Tahun 1999 LN 1999 No 42, pemantau peradilan.

Departemen Pendidikan Nasional,2008, Kamus Besar Bahasa Indonesia Pusat Bahasa, Edisi IV Cet.1, PT Gramedia Pustaka : Jakarta.

Dikdik M.Arief Mansur,Elisatris Gultom, 2005, Cyber Law. Refika Aditama : Bandung.

Harso Wijaya, 2005, Tinjauan Hukum Mengenai Wanprestasi Dalam Jual Beli Secara Elektronik Dihubungkan Dengan Buku III Kitab Undang-Undang Hukum Perdata Tentang Perikatan ,Fakultas Hukum Universitas Kristen Indonesia: Jakarta.

Inosentius Samsul, 2004, Perlindungan Konsumen, Kemungkinan Penerapan Tanggung Jawab Mutlak, Universitas Indonesia : Jakarta.

Johanes Gunawan, Hukum Perlindungan Konsumen, Universitas Katolik Parahyangan, Bandung.
Mariam Darus Badrulzaman, 1994, Aneka Hukum Bisnis, : Alumni : Bandung

Muhammad Ali Sais, Tarikh al-Fiqh al-Islami (Mesir: Mathba'ah al-Nahda,1957); lihat juga Husain Hamid Hasan, $t$, alMadkhal li Dirasat al-Fiqh al-Islami (Mesir: Mathba ah alNahdah).

Muhammad Daud Ali, 2011, Hukum Islam Pengantar Ilmu Hukum dan Tata Hukum Islam di Indonesia, Raja Grafindo persada: Jakarta.

Nasution AZ, 1995, Konsumen dan Hukum, Pustaka Sinar Harapan, Jakarta.

Nasution AZ, 2001, Hukum Perlindungan Konsumen, Diadit Media, Yogyakarta.

Ni Kadek Darmayanti, Upaya Perlindungan Hukum Terhadap Konsumen Online Di Indonesia, Bagian Hukum Perdata Fakultas Hukum Universitas Udayana.

Noel J.Coulson, 1987, Hukum Islam dalam Perspektif Sejarah, P3M : Jakarta.

Nurul Atira, 2017, Jual Beli Online yang Aman dan Syar'i, UIN Alaluddun Makasar : Makasar.

Philipus M. Hadjon,dkk, 2011, Pengantar Hukum Administrasi Indonesia,Gajah Mada University Press : Yogyakarta.

Rahmat Syafe ${ }^{e i}$, Fiqh Muamalah.2001, Cet. X . CV. Pustaka Setia: Bandung.

Satjipto Rahardjo, 2003, Sisi-sisi Lain dari Hukum di Indonesia, Jakarta, Kompas.

Perubahan Sosial, Alumni:

Bandung .

Soerjono Soekanto, 2002, Faktor-faktor yang mempengaruhi Penegakan Hukum, PT Raja Grafindo Persada: Jakarta. 2000, Pokok-pokok Sosiologi hukum, PT.Raja Grafindo persada: Jakarta.

Sriwati, 2000,Perlindungan Hukum Bagi Para Pihak dalam Perjanjian Baku,Yustika : Jakarta.

Teguh Prasetyo, 2005, Bisnis E-Commerce Studi Sistem Keamanan dan Hukum d 
AJUDIKASI : Jurnal Ilmu Hukum, Volume 3 Nomor 2, Desember 2019. Hlm 197-210

Indonesia, Pustaka Pelajar : Yogyakarta.

Undang-undang RI Nomor 11 Tahun 2008 tentang Informasi dan Transaksi Elektronik.

UU No. 8 Tahun 1999 tentang Perlindungan Konsumen. 